\title{
ST
}

Science \& Technology

PAPER - OPEN ACCESS

Efektivitas Model Pembelajaran Learning Cycle Dalam Upaya Meningkatkan Hasil Belajar Kimia Siswa Pada Pokok Bahasan Kesetimbangan Kimia Melalui Pendekatan Penelitian Tindakan Kelas

$\begin{array}{ll}\text { Author } & : \text { Rohazmy Rizki dkk., } \\ \text { DOI } & : 10.32734 / \text { st.v2i1.345 } \\ \text { Electronic ISSN } & : 2654-7082 \\ \text { Print ISSN } & : 2654-7074\end{array}$

Volume 2 Issue 1 - 2018 TALENTA Conference Series: Science \& Technology (ST)

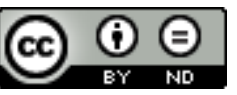

This work is licensed under a Creative Commons Attribution-NoDerivatives 4.0 International License.

Published under licence by TALENTA Publisher, Universitas Sumatera Utara

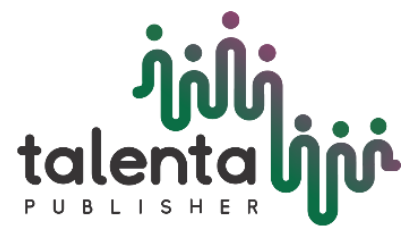




\section{Efektivitas Model Pembelajaran Learning Cycle Dalam Upaya Meningkatkan Hasil Belajar Kimia Siswa Pada Pokok Bahasan Kesetimbangan Kimia Melalui Pendekatan Penelitian Tindakan Kelas}

\author{
Rohazmy Rizki ${ }^{\mathrm{a}}$, Asep Wahyu Nugraha ${ }^{\mathrm{b}}$, Erlina $^{\mathrm{c}}$ \\ ${ }^{a, c}$ Program Studi Pendidikan Kimia, Pascasarjana, Universitas Negeri Medan, Medan \\ ${ }^{b}$ Dosen Jurusan Kimia, Fakultas MIPA, Universitas Negeri Medan, Medan
}

\begin{abstract}
Abstrak
Tujuan dari penelitian ini adalah untuk mengetahui apakah hasil belajardan aktifitassiswa pada pokok bahasan kesetimbangan kimia yang diajar dengan Model Learning Cyclemelalui Pendekatan Penelitian Tindakan Kelas lebih baik dari sebelum diberi tindakan. Penelitian ini telah dilakukan di MAN 2 Model Medan. Populasi penelitian terdiri dari empat kelas dan secara acak diambil satu kelas sebagai sampel. Penelitian ini tidak membandingkan dua buah kelas, hanya melihat hasil awal sebelum diberi perlakuan dan sesudah diberi perlakuan. Penerapan model pembelajaran dilakukan dua siklus dengan observasi untuk mengetahui perubahan aktivitas siswa. Hasil penelitian menunjukkan model pembelajaran efektif digunakan sebagai model pembelajaran. Terdapat peningkatan hasil belajar siswa yang signifikan dari siklus I ke siklus II penerapan model pembelajaran. Hasil observasi menunjukkanminat siswa mendengarkan penjelasan guru, mengerjakan soal, mengajukan pertanyaan dan mencatatpada pokok bahasan kesetimbangan kimia meningkat.
\end{abstract}

Kata kunci: learning cycle, penelitian tindakan kelas, kesetimbangan kimia

\section{Pendahuluan}

Perubahan orientasi dalam bidang pendidikan dari behavioristik (teacher centered) menuju konstruktivisme (student centered) membuat guru tidak lagi satu-satunya sumber informasi, tetapi sebagai fasilitator yang kreatif dan mampu memotivasi siswa serta dapat menciptakan lingkungan belajar yang kondusif. Guru diharuskan lebih selektif dalam pemilihan model pembelajaran yang sesuai dan dapat mengaplikasikan teori belajar konstruktivisme [1].

Siswa dituntut untuk mampu berpikiran kritis, menganalisis, membandingkan, menggeneralisasi, menghipotesis hingga dapat mengambil keputusan dari masalah yang ada. Aktifitas kreatif dan inovatif dari siswa merupakan faktor penting penentu keberhasilan belajar, untuk itu siswa harus selalu aktif dalam proses belajar mengajar. Sejalan dengan teori konstuktivisme, dimana pengetahuan itu bukanlah suatu fakta yang tinggal ditemukan, melainkan suatu perumusan yang diciptakan orang yang sedang mempelajarinya [2].

Model learning cyclemerupakan model pembelajaran yang melibatkan siswa lebih aktif dalam proses belajar mengajar (student centered).Learning cyclemerupakan rangkaian tahap-tahap kegiatan yang dikoordinasikan sedemikian rupa sehingga pembelajaran dapat menguasai kompetensi-kompetensi yang harus dicapai dalam pembelajaran dengan jalan berperan aktif.

Penggunaan model pembelajaran learningcycle dapat meningkatkan kualitas proses dan hasil pembelajaran, dilihat dari meningkatnya motivasi dan partisipasi siswa dalam proses pembelajaran [3]. Learningcycledalam pembelajaran kimia dapat meningkatkan hasil belajar, keaktifan, dan minat siswa dalam proses belajar mengajar [4].

Pendekatan penelitian tindakan kelas adalah penelitian praktis yang dimaksudkan untuk memperbaiki pembelajaran di kelas, yang mana diharapkan dapat meningkatkan efektifitas penggunaan model pembelajaran, dimana guru dapat lebih profesional dalam meningkatkan proses dan kualitas atau hasil pembelajaran di kelas [5] 
Penelitian tindakan kelas (classroomactionresearch)yang dilakukan dalam beberapa siklus dan dalam tiap siklusnya diterapkan pembelajaran kooperatif dapat meningkatkan ketuntasan belajar dan prestasi afektif siswa [6].

Berdasarkan uraian di atas, maka peneliti tertarik melakukan penelitian untuk mengetahui efektivitas penggunaan model Learning Cycle dengan Pendekatan Penelitian Tindakan Kelas terhadap hasil belajar dan aktifitas siswa pada pokok bahasan kesetimbangan kimia.

\section{Metode}

Penelitian ini telah dilaksanakan di MAN 2 Model Medan pada kelas XI tahun ajaran 2009 / 2010, pada bulan Juni 2010. Populasi pada penelitian ini adalah semua kelas XI MAN 2 Model yang terdiri dari 4 kelas dan diambil secara acak satu kelas sebagai sampel penelitian yang kemudian diajar menggunakan model learning cycledengan pendekatan penelitian tindakan kelas.

Pengumpulan data pada penelitian ini mengunakan instrumen tes sebanyak 30 soal berbentuk pilihan berganda, yang disusun dengan lima jawaban yaitu A, B, C, D dan E. Teknik pemberian skor dilakukan secara dikotomi yaitu skor 1 (satu) untuk jawaban benar dan skor 0 (nol) untuk jawaban salah. Instrumen tes digunakan untuk pre-test yang dilakukan sebelum penerapan model pembelajaran, post-test yang dilakukan setelah melakukan penerapan model pembelajaran pada siklus pertama dan post-test yang dilakukan setelah melakukan pembelajaran berdasarkan hasil refleksi siklus pertama.

Teknik analisis dari instrument test menggunakan: (1) Uji validitas test dengan formula korelasi product moment, (2) Uji reliabilitas dengan menggunakan formula Kuder Richardson (KR-20), (3) Uji taraf kesukaran ditentukan atas banyaknya siswa yang menjawab benar butir soal dibanding seluruh siswa yang mengikuti test, dan (4) Uji daya pembeda, ditentukan dari proporsi tes kelompok atas yang dapat menjawab dengan benar. Teknik analisis data terdiri dari uji normalitas, uji homogenitas, uji hipotesis dan uji peningkatan hasil belajar.

Tabel 1. Rancangan penelitian

\begin{tabular}{ccccc}
\hline \multirow{2}{*}{ Pre-test } & \multicolumn{2}{c}{ Siklus I } & \multicolumn{2}{c}{ Siklus II } \\
\cline { 2 - 5 } & Perlakuan & Post-test I & Perlakuan & Post-test II \\
\hline $\mathrm{T}_{1}$ & $\mathrm{X}_{1}$ & $\mathrm{~T}_{2}$ & $\mathrm{X}_{2}$ & $\mathrm{~T}_{3}$ \\
\hline
\end{tabular}

Keterangan:

$\mathrm{X}_{1}$ : Pembelajaran menerapkan model learning cycledengan pendekatan penelitian tindakan kelas.

$\mathrm{X}_{2}$ : Learning cycledengan pendekatan penelitian tindakan kelas berdasarkan hasil refleksi pada siklus I.

$\mathrm{T}_{1}$ : Hasil pre-test eksperimen pada awal penelitian.

$\mathrm{T}_{2}$ : Hasil post-test eksperimen pada akhir penelitian siklus I.

$\mathrm{T}_{3}$ : Hasil post-test eksperimen pada akhir penelitian siklus II.

Pada prosedur penelitian terdiri 2 siklus dan setiap siklus terdiri dari 4 tahap yaitu tahap perencanaan (planning), tahap tindakan (action), tahap pengamatan (observation) dan tahap refleksi (reflection).

Tahap perencanaan (Planning). Tahap perencanaan meliputi: (1) Menyusun perangkat instrumen penelitian berupa: (a) Rencana Pelaksanaan Pembelajaran (RPP); (b) Menyusun instrumen tes hasil belajar berupa soal pilihan berganda; dan (2) Memberikan pre-test yang bertujuan untuk mengetahui kemampuan awal siswa, kemudian dianalisis.

Tahap tindakan (Action). Tahap tindakan meliputi: (3) Melakukan pembelajaran dengan model learning cycle, sesuai dengan rencana pelaksanaanpembelajaran yang telah disusun.

Tahap Pengamatan (Observation). Tahap pengamatan meliputi: (4) Melakukan pengamatan terhadap perilaku siswa. Aspek yang diamati adalah minat siswa, motivasi siswa, keaktifan siswa, dan respon siswa setelah pengajaran dangan modellearning cycle;dan (5) Memberikan tes akhir dengan soal pilihan berganda yang bertujuan untuk mengukur hasil belajar siswa. 
Tahap refleksi (Reflection). Tahap refleksimeliputi:(6) Menganalisis hasil pengamatan terhadap perilaku siswa dan hasil belajar siswa, hasil analisis menjadi acuan menuju siklus 2; (7) Melaksanakan tabulasi data danmendeskripsikan data hasil penelitian; (8)Melakukan uji homogenitas, ujinormalitas danefektifitas; (10)Membuat kesimpulan; dan (11) Menyusun laporan akhir penelitian.

\section{Hasil dan Pembahasan}

Data hasil belajar. Dari perhitungan berdasarkan data tabulasi hasil tes diperoleh hasil rata-rata nilai pre-test adalah 27,35, rata-rata nilai post-test 1 adalah 67,35 serta rata-rata nilai post-test 2 adalah 87,65 yang dirangkum dalam Gambar 1.Pada gambar 1 dapat dilihat bahwa terdapat peningkatan hasil belajar dari pre-test ke post-test 1 (siklus 1) sebesar 40 dan post-test 1 ke post-test 2(siklus 2) sebesar 20. Nilai pre-testke post-test 1 dapat meningkat setelah dilakukan pendekatan penelitian tindakan kelas yang dilaksanakan dengan model pembelajaran learning cycle. Berdasarkan hasil refleksi siklus 1, peneliti lebih memfokuskan perbaikan pada teknik pengajaran dan mengaplikasikan konstruktivisme melalui model pembelajaran yang membuat adanya peningkatannilai post-test 1 ke post-test 2 .

Pre-test $\mathbf{0}$ Post-test 1 Post-test 2

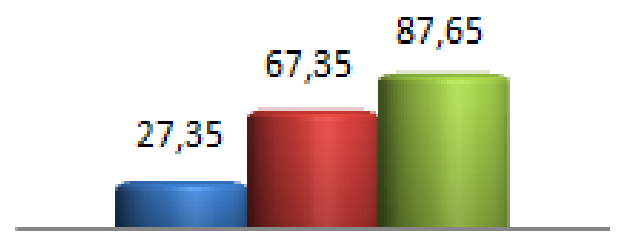

Gambar 1. Diagram Hasil Rata-Rata pre-test, post-test 1 dan post-test 2

Data hasil pengamatan. Jenis kegiatan siswa yang diamati pada tahap ini adalah mendengarkan penjelasan, antusias siswa menyelesaikan soal, keaktifan siswa mengajukan pertanyaan, mencatat rangkuman pelajaran dan kedisiplinan.

Dari perhitungan berdasarkan data tabulasi hasil pengamatan diperoleh persentase skor tiap jenis kegiatan yang diamatidirangkum dalam Tabel 2

Tabel 2. Persentase skor hasil pengamatan

\begin{tabular}{lcc}
\hline \multicolumn{1}{c}{ Jenis Kegiatan } & $\begin{array}{c}\text { Jumlah Skor } \\
\text { Siklus 1 (\%) }\end{array}$ & $\begin{array}{c}\text { Jumlah Skor } \\
\text { Siklus 1 (\%) }\end{array}$ \\
\hline Mendengarkan penjelasan guru & 46,08 & 92,16 \\
Antusias menyelesaikan soal & 50,00 & 81,37 \\
Aktif mengajukan pertanyaan & 42,16 & 79,41 \\
Mencatat rangkuman pelajaran & 49,02 & 92,16 \\
Kedisiplinan & 62,75 & 93,14 \\
\hline
\end{tabular}

Dari tabel 2 dapat dilihat pada pembelajaran siklus 1 hanya 50\% siswa yang aktif dalam mengikuti pembelajaran, hal ini sebabkan kurang minat dan kesiapan siswa dalam menerima pembelajaran. Berdasarkan hasil pengamatan siklus 1, pada siklus 2 dilakukan perbaikan pada minat dan kesiapan siswa dalam menerima pelajaran dengan memberikan pengarahan dan motivasi, melakukan pembelajaran yang lebih aktif, mengajukan pertanyaanpertanyaan yang merata kepada siswa dengan penghargaan nilai tambahan apabila dapat menjawab pertanyaan dengan baik, yang membuat terjadinya peningkatan minat siswa dalam mengikuti pelajaran. 
Uji normalitas data. Sebelum menganalisis data, data-data yang diperoleh harus memenuhi syarat yaitu berdistribusi normal. Untuk itu dilakukan uji normalitas terhadap data hasil penelitian. Untuk mengetahui apakah data pre-test, post-test 1 dan post-test 2 terdistribusi normal atau tidak, maka dilakukan uji Lilieforspada taraf nyata $\mathrm{a}=0,05$. Berdasarkan hasil uji normalitas pada data pre-test dan post-test diperoleh data seperti pada tabel 3 .

Tabel 3. Uji normalitas data pre-test, post-test 1 dan post-test 2

\begin{tabular}{ccccc}
\hline Sumber data & $\mathrm{t}_{\text {hitung }}$ & $\mathrm{t}_{\text {tabel }}$ & $\alpha$ & Keterangan \\
\hline Pre-test & 0,2291 & 0,1500 & 0,05 & data normal \\
Post-test 1 & 0,2643 & 0,1500 & 0,05 & data normal \\
Post-test 2 & 0,3192 & 0,1500 & 0,05 & data normal \\
\hline
\end{tabular}

Efektifitaspembelajaran. Untuk mengetahui efektifitas model learning cycledengan pendekatan penelitian tindakan kelas terhadap hasil belajar kimia siswa pada pokok bahasan kesetimbangan kimia, dilakukan perhitungan efektifitas treatment dengan menggunakan data pre-test, post-test 1 dan post-test 2 . Berdasarkan perhitungan efektifitas treatment diperoleh hasil $t_{\text {hitung }}$ siklus $1=38,83$, $t_{\text {hitung }}$ siklus $2=14,19$ dan $t_{\text {tabel }}=2,0411$. Karena $t_{\text {hitung }}>$ $t_{\text {tabel. }}$. Dengan demikian dapat dinyatakan model learning cycledengan pendekatan penelitian tindakan kelas efektif digunakan sebagai model pembelajaran.

\section{Kesimpulan}

Berdasarkan hasil penelitian yang telah dilakukan maka dapat diambil kesimpulan yaitu: (1) Terdapat peningkatan hasil belajar siswa yang diajarkan dengan menggunakan model pembelajaran Learning Cycle dengan Pendekatan Penelitian Tindakan Kelas dari postest siklus I $=67,35$ ke postest siklus II = 87,65; (2) Terdapat peningkatan aktifitas siswa yang dapat dilihatdari minat siswa dalam mengikuti kegiatan pembelajaran; (3) Model learningcycle dengan pendekatan penelitian tindakan kelas efektif digunakan sebagai model pembelajaran.

\section{Referensi}

[1] Budiningsih, A., 2005. Belajar dan Pembelajaran.Rineka Cipta, Jakarta.

[2] Sardiman, A.M., 2005. Interaksi dan Motivasi Belajar Mengajar.Raja Grafindo Persada, Jakarta.

[3] Sugianto, 2011.Penggunaan Model Pembelajaran Siklus Belajar dan Belajar Kooperatif Tipe STAD untuk Meningkatkan Kualitas Proses dan Hasil Belajar Azaz Teknik Kimia Siswa Kelas X SMK Putra Indonesia Malang (PTK).http://www.putraindonesiamalang.or.id/abstrakpenelitian-tindakan-kelas.html (diakses 15 April 2017)

[4] Fajaroh, F., Dasna, I.W., 2004. Penggunaan Model Pembelajaran Learning Cycle Untuk Meningkatkan Motivasi Belajar Dan Hasil Belajar Kimia Zat Aditif Dalam Bahan Makanan Pada Siswa Kelas Ii Smu Negeri 1 Tumpang - Malang. Jurnal Pendidikan dan Pembelajaran,11:112-122.

[5] Muhardjito, 2005. Diklat Teknis Penelitian Tindakan Kelas Guru Pendidikan Luar Biasa. Ditjen Manajemen Pendidikan Dasar dan Menengah Direktorat Pembinaan Sekolah Luar Biasa, Jakarta.

[6] Fajri, L., Martini, K.S., Nugroho, A., 2012. Upaya Peningkatan Proses dan Hasil Belajar Kimia Materi Koloid Melalui Pembelajaran Kooperatif Tipe TGT (TeamsGamesTournament) Dilengkapi Dengan Teka-Teki Silang Bagi Siswa Kelas XI IPA 4 SMA Negeri 2 Boyolali Pada Semester Genap Tahun Ajaran 2011/2012.Jurnal Pendidikan Kimia, 1:89-96. 